JAMP: Jurnal Adminitrasi dan Manajemen Pendidikan

Volume 2 Nomor 3 September 2019, Hal : 167-171

Tersedia Online di http://journal2.um.ac.id/index.php/jamp/

ISSN 2615-8574 (online)

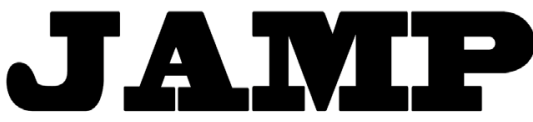

JURNAL ADMINISTRASI DAN MANAJEMEN PENDIDIKAN

\title{
ANALISIS FAKTOR-FAKTOR YANG MEMPENGARUHI PESERTA DIDIK DALAM PEMILIHAN SEKOLAH LANJUTAN TINGKAT ATAS
}

\author{
Ida Putri Lestari \\ Ahmad Yusuf Sobri \\ Desi Eri Kusumaningrum \\ Universitas Negeri Malang, jalan Semarang 5 Malang 65145
e-mail: idaputri043@gmail.com
}

\begin{abstract}
The purpose of this study was to know (1) what are the factors the influence students in the selection of high school in Blitar City, (2) the high level of factors that effects students in the selection of high school in Blitar City, (3) the dominant factors affecting participant students in the selection of high school in Blitar City. This research uses a quantitative approach and is include in the type of descriptive research with exploratory analysis technique. The total population in this study was 3722 . Determination of the sample using the Random Sampling technique with calculations using the Slovin Formula as many as 361 respondents, with a 5\% error chance. Data collection tools use a questionnaire in the form of a positive statement with the assessment using a Likert Scale on each item statement. The results showed factors that influence students in selecting schools, namely: facility factors $(16.60 \%)$, human resource factors (HR) (10.98\%), and superior school factors (9.66\%). This study was able to explain $37.25 \%$ of students' factors in choosing schools, due to the limitations of the factors in this study so that $62.75 \%$ could not be explained such as school location factors, tuition fees, extracurricular activities, and education quality.
\end{abstract}

Key Words: analysis factors, choosing school, leaners

\begin{abstract}
Abstrak: Tujuan penelitian ini mengetahui (1) faktor yang mempengaruhi peserta didik dalam pemilihan SLTA Negeri di Kota Blitar, (2) tingginya tingkat faktor yang mempengaruhi peserta didik dalam pemilihan SLTA Negeri di Kota Blitar, (3) faktor dominan yang mempengaruhi peserta didik dalam pemilihan SLTA Negeri di Kota Blitar. Penelitian ini menggunakan pendekatan kuantitatif dan termasuk dalam jenis penelitian deskriptif dengan teknik analisis eksploratori. Jumlah populasi pada penelitian ini sebanyak 3722 responden. Penentuan sampel menggunakan teknik Random Sampling dengan perhitungan menggunakan Rumus Slovin yaitu sebanyak 361 responden, dengan peluang eror $5 \%$. Alat pengumpulan data menggunakan angket dalam bentuk pernyataan positif dengan penilaian menggunakan Skala Likert pada setiap butir pernyataan. Hasil penelitian menunjukkan faktor yang mempengaruhi peserta didik dalam memilih sekolah, yaitu: faktor sarana $(16.60 \%)$, faktor sumber daya manusia (SDM) (10.98\%), dan faktor sekolah unggul (9.66\%). Penelitian ini mampu menjelaskan $37.25 \%$ faktor peserta didik dalam memilih sekolah, karena keterbatasan faktor pada penelitian ini sehingga $62.75 \%$ belum bisa dijelaskan seperti faktor lokasi sekolah, biaya pendidikan, ekstrakurikuler, dan mutu pendidikan.
\end{abstract}

Kata Kunci: analisis faktor, memilih sekolah, peserta didik

Pendidikan merupakan kebutuhan hidup yang diperlukan oleh setiap orang, baik dari kalangan anakanak, remaja, dewasa, ataupun orangtua, semua membutuhkan pendidikan. Mutu pendidikan yang baik menghasilkan penerus bangsa yang baik. Berdasarkan Jatikom (2018) mutu pendidikan di Indonesia dipengaruhi beberapa faktor antara lain, yaitu: 1) kualitas sarana; 2) kualitas guru; 3) kesejahteraan guru; 4) pemerataan kesempatan pendidikan; 5) relevansi pendidikan dengan kebutuhan; dan 6) biaya pendidikan. Dapat dijelaskan rendahnya kualitas sarana dapat menghambat proses pembelajaran peserta 
didik, sehingga berdampak pada mutu pendidikan yang dihasilkannya. Misalnya sekolah memiliki gedung yang rusak, buku perpustakaan yang tidak lengkap, dan prasarana yang tidak sesuai standar, permasalahan tersebut dapat menghambat proses peningkatan mutu pendidikan. Kemudian kualitas guru atau pendidik merupakan cerminan kualitas dari mutu pendidikan. Meskippun bukan satu-satunya faktor penentu keberhasilan pendidikan, namun pendidik memberikan andil besar pada kualitas pendidikan. Kesejahteraan guru merupakan hal yang mampu mempengaruhi tingkat kualitas guru. Rendahnya kesejahte-raan guru berdampak pada kualitas guru yang rendah, bila kesejahteraan guru pada taraf yang ideal maka memberikan dampak pada kualitas guru yang bagus. Hasil penelitian oleh Murwati (2013) menunjukkan bahwa terdapat pengaruh sertifikasi guru terhadap motivasi kerja (59.2\%), dan kinerja guru (46.7\%). Dari hasil penelitian tersebut dapat disimpulkan bahwa kesejahteraan guru mempengaruhi motivasi kerja dan kinerja guru yang berdampak pula pada pendidikan di sekolah. Oleh karena itu diperlukan upaya-upaya atau strategi untuk mengatasi ketidakmerataan kesempatan pendidikan tersebut. Menurut Idrus (2012) pemerataan pendidikan, mutu pendidikan, relevansi pendidikan, dan efisiensi pengelolaan pendidikan perlu ditingkatkan secara menyeluruh dan seimbang dilihat dari kemampuan dan kebutuhan masing-masing daerah dan pemerintah turut serta dalam meningkatkan mutu pendidikan.

Relevansi pendidikan juga perlu diperhatikan, banyaknya lulusan yang menganggur setelah menempuh pendidikan dapat dikarenakan ketidaksesuaian dari kurikulum materinya dengan keterampilan yang dibutuhkan. Pendidikan memang membutuhkan biaya yang mahal untuk memperoleh pendidikan yang menjadi berkualitas atau bermutu. Biaya pendidikan harus didapatkan oleh semua warga Indonesia guna investasi dimasa mendatang. Sebab itu, pemerintah dengan kebijakan-kebijakannya bertanggung jawab untuk menjamin setiap warganya dapat memperoleh pendidikan yang terbaik.

Banyaknya pilihan sekolah yang tersedia, peserta didik jelas tidak mudah dalam menentukan sekolah mana yang akan dipilih. Sekolah yang terpilih tentunya berdasarkan pertimbangan-pertimbangan atau alasan mengapa memilih sekolah tersebut. Hal ini sebagaimana diperkuat oleh hasil penelitian Andryana (2009), yang mengungkapkan bahwa faktor yang paling berpengaruh dalam pemilihan Sekolah Dasar (SD) adalah mutu pendidikan (38.2\%), kemudian lokasi sekolah (25\%), fasilitas sekolah (16\%), biaya pendidikan (10.1\%), spiritual (6.4\%), dan ekstrakurikuler (5.5\%). Dari 10 SD di Kota Depok yang menjadi alternatif sekolah, SD Tugu Ibu merupakan alternatif sekolah terbaik (19.1\%), sedangkan SD Negeri Sukmajaya $5(11.5 \%)$ berada pada urutan kedua. Berdasarkan penelitian tersebut dapat disimpulkan bahwa peserta didik dalam memilih sekolah dipengaruhi oleh beberapa faktor, yaitu mutu pendidikan, lokasi sekolah, fasilitas sekolah, biaya pendidikan, spiritual, dan ekstrakurikuler.

Berdasarkan hasil penelitian tersebut terdapat keterikatan dengan penelitian ini yaitu memiliki tujuan yang sama, yaitu untuk mengetahui faktor-faktor peserta didik dalam pemilihan sekolah, tingkat pengaruh faktor dalam pemilihan sekolah, dan faktor dominannya meskipun penelitian dengan menggunakan teknik analisis yang berbeda. Kota Blitar merupakan kota yang terdapat beberapa jenis SLTA, yakni meliputi: SMA Negeri dan SMA Swasta, MA Negeri dan SMA Swasta, SMK Negeri dan SMK Swasta. Jenis SLTA di Kota Blitar juga dimungkinkan mempengaruhi minat anak-anak usia SLTA yang bersekolah. Lokasi sekolah serta fasilitas dan layanan yang disediakan juga mempengaruhi peserta didik dalam pemilihan sekolah lanjutan yang akan dipilihnya. Peserta diidik dalam pemilihan sekolah yang dijadikan tempat untuk menimba ilmu, tentunya selalu memiliki berbagai faktor yang dijadikan sebagai alasan dalam pemilihan sekolah. Faktor-faktor tersebut dipertimbangkan dengan matang, supaya tidak slaah dalam memilih sekolah. Tujuan dari penelitian ini yaitu, untuk mengetahui: 1) faktor-faktor yang mempengaruhi peserta didik dalam pemilihan SLTA Negeri di Kota Blitar, 2) tingginya tingkat faktor yang mempengaruhi peserta didik dalam pemilihan SLTA Negeri di Kota Blitar, dan 3) faktor dominan yang mempengaruhi peserta didik dalam pemilihan SLTA Negeri di Kota Blitar.

\section{METODE}

Pendekatan yang digunakan yaitu pedekatan kuantitatif dengan jenis penelitian yaitu deskriptif. Kegiatan anaisis data ini dilakukan setelah terkumpulnya semua data dari responden yang telah ditentukan, yaitu mengelompokkan data berdasarkan variable, mentabulasi data berdasarkan variabel 
seluruh responden, dan menyajikan data setiap variabel yang diteliti. Penelitian ini dilakukan di SLTA Negeri di Kota Blitar yang terdiri dari Sekolah Menengah Atas (SMA) Negeri 1, 2, 3, dan 4, Sekolah Menengah Kejuruan (SMK) Negeri 1, 2, 3, dan Madrasah Aliyah (MA) Negeri Kota Blitar. Populasi pada penelitian ini adalah peserta didik SLTA Negeri Kota Blitar sebanyak 3722, dan sampel ditentukan dengan menggunakan Rumus Slovin dengan peluang eror 5\%, yaitu sebanyak 361 peserta didik yang menjadi responden. Pengumpulan data dengan menggunakan angket yang diberikan kepada sampel yang telah ditentukan. Angket tersebut dalam bentuk butir-butir pernyataan positif sebanyak 38 butir, dengan penilaian menggunakan Skala Likert pada setiap butir pernyataan.

Analisis data pada penelitan ini menggunakan analisis faktor eksploratori. Persyaratan dalam analisis faktor eksploratori, yaitu data berdistribusi normal. Berdasarkan uji normalitas data dengan program SPSS menggunakan Kolmogorov Smirnov Test, data pemilihan sekolah peserta didik menunjukkan hasil distribusi normal. Syarat normalitas data yaitu nilai signifikansinya $>0,05$ dan hasil analisis data ini menunjukkan nilai signifikansinya sebesar 0,494 . Selanjutnya uji homogenitas dengan program SPSS, data pemilihan sekolah peserta didik menunjukkan varians yang sama atau homogen. Syarat data dapat dikatakan homogen yaitu nilai signifikansinya $>0,05$ dan hasil analisis data ini menunjukkan nilai signifikansinya sebesar 0,127 . Uji analisis faktor dilakukan dengan menggunakan SPSS for windows versi 16.0. analisis faktor juga memperoleh hasil Kaiser Mayer Olkin (KMO) dan Bartleet's Test of Sphericity (Sig) sebesar 0,740 dan nilai signifikan 0,000. Apabila nilai $\mathrm{KMO}>0,5$ dengan nilai signifikan $<0,05$ maka analisis faktor dalam penelitian ini sudah tepat dan dapat dilanjutkan karena telah memenuhi persyaratan.

\section{HASIL}

Berdasarkan analisis eksploratori, nilai Eigenvalue $\geq 1$ teridentifikasi sebanyak 3 faktor. Nilai persentase kumulatifnya sebesar $37,257 \%$, maka hasil analisis dapat digunakan untuk menafsirkan temuan-temuan konsep baru yang muncul. Pada peenelitian ini, ditemukan dan dihasilkan 3 kelompok yang telah diberikan nama sebagai konsep baru sesuai dengan pernyataan-peernyataan yang mengelompok, yaitu faktor sarana, faktor SDM dan faktor sekolah unggul. Faktor sarana memiliki jumlah muatan faktoor sebesar 26,18 (16.604\%). Muatan faktor tersebut berasal dari item-item yang mengelompok, yaitu: item 22 sebesar $(0,676)$, item 16 sebesar $(0,67)$, item 3 sebesar $(0,645)$, item 17 sebesar $(0,643)$, item 15 sebesar $(0,59)$, item 21 sebesar $(0,58)$, item 24 sebesar $(0,58)$, item 20 sebesar $(0,56)$, item 19 sebesar $(0,53)$, item 18 sebesar $(0,52)$, item 31 sebesar $(0,52)$ item 25 sebesar $(0,51)$, item 28 sebesar $(0,51)$, item 34 sebesar $(0,48)$, item 26 sebesar $(0,48)$, item 27 sebesar $(0,48)$, dan item 33 sebesar $(0,42)$. Berdasarkan hasil analisis deskriptif dapat diketahui pada faktor sarana bahwa sebanyak 16 responden menyatakan sangat tidak setuju, 103 responden menatakan tidak setuju, 189 responden menyatakan setuju, 53 responden menyatakan sangat setuju, dengan nilai mean sebesar 53,0.4.

Selanjutnya diketahui faktor SDM memiliki muatan faktor sebesar 6,304 (10.987\%). Muatan faktor tersebut berasal dari item-item yang mengelompok, yaitu: item 6 sebesar $(0,623)$, item 12 sebesar $(0,599)$, item 5 sebesar $(0,589)$, item 2 sebesar $(0,583)$, item 7 sebesar $(0,566)$, item 1 sebesar $(0,549)$, item 11 sebesar $(0,49)$, item 3 sebesar $(0,467)$, item 4 sebesar $(0,454)$, item 13 sebesar $(0,417)$, item 32 sebesar $(0,39)$, item 14 sebesar $(0,369)$, item 10 sebesar $(0,344)$, dan item 9 sebesar $(0,305)$. Berdasarkan analisis deskriptif dapat diketahui bahwa sebanyak 3 responden menyatakan sangat tidak setuju, 97 menyatakan tidak setuju, 166 responden menyatakan setuju, dan 95 menyatakan sangat setuju. Faktor SDM memiliki nilai mean sebesar 27,48.

Sedangkan faktor sekolah unggul memiliki jumlah muatan faktor sebesar 4,769 (9.666\%). Muatan faktor pada faktor sekolah unggul berasal dari item 8 sebesar $(0,227)$, item 35 sebesar $(0,793)$, item 36 sebesar $(0,778)$, item 38 sebesar $(0,523)$, item 37 sebesar $(0,523)$, item 29 sebesar $(0,369)$, dan item 30 sebesar $(0,356)$. Berdasarkan analisis deskriptif, faktor sekolah unggul dapat diketahui bahwa sebanyak 1 responden menyatakan sangat tidak setuju, 43 responden menyatakan tidak setuju, 216 menyatakan setuju, dan 101 responden menyatakan sangat setuju, dengan nilai mean sebesar 23,51. Hasil dari penelitian ini dapat diketahui faktor dominan yang mempengaruhi peserta didik dalam pemilihan SLTA 
Negeri di Kota Blitar adalah faktor sarana dengan persentase sebanyak 16,604\%. Sedangkan pada faktor SDM persentasenya sebesar $10,987 \%$, dan faktor sekolah unggul persentasenya sebesar $9,666 \%$.

\section{PEMBAHASAN}

Sekolah merupakan lembaga pendidikan yang menyelenggarakan kegiatan belajar dan mengajar serta menerima dan memberi pelajaran sesuai dengan tingkat jurusan dan sebagainya, yang memiliki unsusr pendukung sesuai aturan yang berlaku. Dalam menentukan sekolah diperlukan perencanaan yang benar-benar matang, karena pendidikan sangat penting dalam kehidupan. Banyak faktor yang mempengaruhi peserta didik dalam pemilihan sekolah. Dalam penelitian ini ditemukanan ada 3 faktor yang mempengaruhi peserta didik dalam memilih sekolah yaitu, faktor sarana, faktor SDM, dan faktor sekolah unggul. Penelitian ini menunjukkan faktor saran merupakan faktor yang mempengaruhi peserta didik dalam pemilihan sekolah. Hasil penelitian tersebut sejalan dengan Novita (2012) yang menunjukkan salah satu faktor alasan memilih sekolah yaitu sekolah mempunyai fasilitas yang lengkap. Tersedianya media pembelajaran yang lengkap dan masih dalam keadaan yang baik mampu menunjang kualitas belajara peserta didik. Jadi dari penelitian tersebut dapat disimpulkan bahwa sarana yang disediakan sekolah merupakan faktor peserta didik dalam memilih sekolah karena memiliki pengaruh dalam proses pembelajaran peserta didik di sekolah. Sarana pada sekolah yang diteliti memiliki kuantitas yang cukup, namun dalam proses pembelajaran kurang efektif karena sarana yang tersedia terdapat beberapa dalam keadaan kurang bagus atau kurang baik. Sedangkan untuk prasarana di sekolah yang diteliti sudah bagus, maka diperlukan perawatan yang berkala sehingga prasarana yang ada tetap terjaga.

Kemudian faktor SDM di sekolah yaitu pendidik dan tenaga kependidikan. Pendidik dan tenaga kependidikan merupakan unsur yang memiliki andil besar dalam proses pendidikan di sekolah. Kesejahteraan guru berpengaruh dalam menciptakan guru yang berkualitas dan berdampak pada pendidikan yang diberikan di sekolah. Sejalan dengan penelitian Murwati (2013) menunjukkan bahwa terdapat pengaruh sertifikasi profesi guru terhadap motivasi kerja dan kinerja guru. Diperkuat dengan penelitian Yacob (2014) yang mengungkapkan bahwa faktor keempat dalam pemilihan sekolah yaitu guru yang berkualitas yang dimiliki sekolah. Berdasarkan penelitian tersebut dapat disimpulkan bahwa kesejahteraan guru mempengaruhi motivasi kerja dan kinerja guru yang selanjutnya berdampak pada kualitas guru dan pendidikan di sekolah.

Selanjutnya faktor sekolah unggul pada penelitian ini merupakan faktor yang mempengaruhi peserta didik dalam pemilihan sekolah. Pada dasarnya semua sekolah memiliki tujuan untuk memberikan pelayanan pendidikan yang terbaik untuk peserta didiknya. Sekolah dengan memiliki mutu pendidikan yang baik tentunya akan mempengaruhi peserta didik dalam menentukan sekolah lanjutan. Sejalan dengan penelitian Solmon (2003) yang mengungkapkan bahwa orang tua memilih sekolah terbaik untuk anak-anak mereka karena prestasi akademik peserta didik atau kualitas akademik mereka lebih penting untuk kepentingan jangka panjang terbaik anak. Diperkuat dengan penelitian Andryana (2009) yang mengungkapkan bahwa mutu pendidikan merupakan faktor utama yang mempengaruhi peserta didik dalam pemilihan sekolah. Dari penelitian tersebut dapat disimpulkan bahwa mutu pendidikan memiliki pengaruh terhadap peserta didik dalam pemilihan sekolah.

Pada penelitian ini faktor sarana merupakan faktor dominan yang mempengaruhi peserta didik dalam pemilihan sekolah, yaitu sebesar $16.60 \%$, sedangkan faktor SDM memiliki pengaruh sebesar $10.98 \%$ dan faktor sekolah unggul sebesar 9.66\%. Hasil dari penelitian mampu menjelaskan $37.25 \%$ faktor yang mempengaruhi peserta didik dalam pemilihan SLTA Negeri di Kota Blitar. Dari $100 \%$ faktor yang mempengaruhi peserta didik dalam pemilihan sekolah, masih terdapat $62.75 \%$ yang belum bisa dijelaskan pada penelitian ini. Hal tersebut dikarenakan pada penelitian ini terbatas pada faktor-faktor yang diteliti. Berdasarkan penelitian sebelumnya yang dilakukan oleh Andryana (2009) menunjukkan bahwa hasil penelitiannya yaitu faktor yang mempengaruhi peserta didik dalam memilih sekolah adalah mutu pendidikan, lokasi sekolah, fasilitas sekolah, biaya pendidikan dan ekstrakurikuler. Dari penelitian penelitian tersebut dapat disimpulkan bahwa masih terdapat faktor-faktor lain yang mempengaruhi peserta didik dalam SLTA Negeri di Kota Blitar yang belum dijelaskan pada penelitian ini karena terbatas 
faktor penelitian. Faktor yang belum dijelaskan pada penelitian ini sebesar $62.75 \%$ tersebut bisa jadi dari faktor lain seperti lokasi sekolah, biaya pendidikan, dan ekstrakurikuler. Lokasi sekolah yang strategis juga mempengaruhi peserta didik dalam memilih sekolah. Sekolah yang terletak diperkotaan memiliki akses jalan yang mudah, banyak transportasi yang bisa digunakan untuk ke sekolah. Biaya pendidikan juga mempengaruhi peserta didik dalam memilih sekolah. Sekolah yang bermutu atau unggul tentunya membutuhkan biaya pendidikan yang mahal. Pendidikan sangat penting dalam kehidupan karena dengan pendidikan yang bermutu mampu merubah peserta didik menjadi berprestasi dan mampu merubah perekonomian dimasa mendatang. Seperti pepatah "Jer Basuki Mowo Beo" yang artinya untuk mencapai keberhasilan diperlukan biaya atau pengorbanan. Kemudian faktor ekstrakurikuler, ektrakurikuler yang ada di sekolah juga mempengaruhi peserta didik dalam memilih sekolah. Ekstrakurikuler merupakan salah satu sarana yang menaungi bakat dan atau hobi peserta didik yang bisa menunjang prestasi non akademiknya. Ekstrakurikuler yang beragam dan mampu menghasilkan prestasi di sekolahnya tentu mempengaruhi minat peserta didik. Dari ekstrakurikuler itulah bakat peserta didik dapat dikembangkan agar dapat mengimbangi prestasi akademiknya.

\section{SIMPULAN}

Faktor-faktor yang mempengaruhi peserta didik dalam pemilihan SLTA Negeri di Kota Blitar, yaitu antara lain: a) faktor sarana yaitu kelengkapan fasilitas yang disediakan sekolah, b) faktor SDM yaitu kualifikasi pendidik dan tenaga kependidikan yang sesuai dengan tugas dan tanggungjawab, dan c) faktor sekolah unggul yaitu sekolah memiliki mutu pendidikan yang bagus untuk peserta didiknnya. Tingkatan faktor yang mempengaruhi peserta didik dalam pemilihan sekolah yaitu: sarana $16.60 \%$, SDM $10.98 \%$, dan sekolah unggul 9.66\%. Faktor dominan yang mempengaruhi peserta didik dalam pemilihan SLTA Negeri di Kota Blitar adalah faktor sarana 16.60\%.

\section{DAFTAR RUJUKAN}

Andryana, S. (2009). Analisa Faktor-Faktor Yang Mempengaruhi Pemilihan Sekolah Dasar Di Kota Depok Menggunakan Metode Proses Analisa Bertingkat. Jurnal Basis Data, ICT Research Center UNAS, 4(1), 24-43. http://old.unas.ac.id/detail_publikasi_jurnal/190_analisa_faktor-faktor_yang_mempengaruhi_pemilihan_ sekolah_dasar_di_kota_depok_menggunakan_metode_pro.

Bast, J. L. \& Walberg, H. J. (2003). Can Parents Choose The Best Schools For Their Children?. Economic of Education Review, 23(4), 431-440. sciencedirect.com/science/article/abs/pii/S0272775703001213.DOI: http://doi.org/10.1016/j.econedurev.2003.08.003.

Idrus, M. (2012). Mutu Pendidikan dan Pemerataan Pendidikan di Daerah. Psikopedagogia, 1(2), $2301-6167$. http://journal.uad.ac.id/index.php/PSIKOPEDAGOGIA/article/viewFile/4603/2809.

Jatikom. (2018). Peningkatan Pendidikan Di Indonesia (Online), (https://sahabatkeluarga.kemdikbud.go.id/ forum/showthread.php?tid=18430), diakses pada 11 Juli 2019.

Murwati, H. (2013). Pengaruh Sertifikasi Profesi Guru Terhadap Motivasi Kerja dan Kinerja Guru di SMK Negeri se-Surakarta. Jurnal Pendidikan Bisnis dan Ekonomi (BISE), 1(1), 12-21. https://eprints.uns. ac.id/1083/1/1896-4270-1-SM.pdf.

Novita, M. (2012). Pemetaan Animo Lulusan Sekolah Dasar (SD)/Madrasah Ibtidaiyah (MI) dan Rasio Enrollment Sekolah Lanjutan Tingkat Pertama (SLTP) Se-Kecamatan Pagelaran Kabupaten Malang (Online), (http:// karya-ilmiah.um.ac.id/index.php/ASP/article/view/20299), diakses 21 Juli 2019.

Yacob, N. A., Osman, M. M. \& Bachok, S. (2014). Factors Influencing Parents'Decisoin in Choosing Private Schools. Procedia - Social and Behavioral Science, 153(), 242-253. DOI: http://doi.org/10.1016/j. sbspro.2014.10.058. 